\title{
Disruption of the HNF-4 gene, expressed in visceral endoderm, leads to cell death in embryonic ectoderm and impaired gastrulation of mouse embryos
}

\author{
William S. Chen, ${ }^{1,4}$ Katia Manova, ${ }^{3,4}$ Daniel C. Weinstein, ${ }^{1,4}$ Stephen A. Duncan, ${ }^{1}$ \\ Andrew S. Plump, ${ }^{2}$ Vincent R. Prezioso, ${ }^{1}$ Rosemary F. Bachvarova, ${ }^{3}$ and James E. Darnell Jr. ${ }^{1,5}$ \\ ${ }^{1}$ Laboratory of Molecular Cell Biology, ${ }^{2}$ Laboratory of Biochemical Genetics and Metabolism, The Rockefeller University, \\ New York, New York 10021 USA; ${ }^{3}$ Department of Cell Biology and Anatomy, Cornell University Medical College, \\ New York, New York 10021 USA
}

Expression of HNF-4, a transcription factor in the steroid hormone receptor superfamily, is detected only in the visceral endoderm of mouse embryos during gastrulation and is expressed in certain embryonic tissues from 8.5 days of gestation. To examine the role of HNF-4 during embryonic development, we disrupted the gene in embryonic stem cells and found that the homozygous loss of functional HNF-4 protein was an embryonic lethal. Cell death was evident in the embryonic ectoderm at 6.5 days when these cells normally initiate gastrulation. As assessed by expression of Brachyury and HNF-3 3 , primitive streak formation and initial differentiation of mesoderm do occur, but with a delay of $\sim 24 \mathrm{hr}$. Development of embryonic structures is severely impaired. These results demonstrate that the expression of HNF-4 in the visceral endoderm is essential for embryonic ectoderm survival and normal gastrulation.

[Key Words: Transcription factor; gastrulation; HNF; embryonic development; mouse]

Received June 28, 1994; revised version accepted August 18, 1994.

There are several routes to uncover genes that play crucial roles in early mouse development. The most common has been to obtain mammalian genes that are homologous to important developmental genes in invertebrates, particularly Drosophila. A second approach involves insertional mutagenesis, and a third quite limited approach is positional cloning of an already identified gene with an embryonic phenotype.

We have followed another route, that is, to identify transcription factors that direct liver-specific gene expression in the adult and examine their expression during early development. By analysis of proteins bound to the 5' regulatory regions of $\alpha_{1}$-antitrypsin, transthyretin, and $\alpha$-fetoprotein, we were able to clone transcription factors hepatocyte nuclear factor (HNF)-3 $\alpha, 3 \beta, 3 \gamma$, and HNF-4, which are highly expressed in liver; studies of the expression patterns of these genes reveal that they may not only be involved in determination and differentiation during organogenesis but also in earlier embryogenesis. One example is provided by HNF-3 $\beta$, which is expressed in several endodermally derived tissues in the adult animal (Lai et al. 1991; Xanthopoulos et al. 1991) and is expressed in the node, notochord, floor plate, and

\footnotetext{
${ }^{4}$ The first three authors contributed equally to this work. ${ }^{5}$ Corresponding author.
}

gut during early mouse development (Ang et al. 1993; Monaghan et al. 1993; Ruiz i Altaba et al. 1993; Sasaki and Hogan 1993). The HNF-3 family members were found to contain a DNA-binding region homologous to that of the Drosophila gene fork head, which when mutated results in absence of the foregut and hindgut (Weigel et al. 1989). Recently, targeted disruption of the HNF$3 \beta$ gene has been found to be lethal and early embryogenesis severely defective (Weinstein et al. 1994). The expression pattern of HNF-4 (Duncan et al. 1994) and the phenotype of embryos lacking functional HNF-4 described here provide another example of a critical function for an adult tissue-specific transcription factor in the early embryo.

HNF-4 belongs to the steroid/thyroid hormone receptor superfamily and is a positive activator for transcription of many genes expressed in the liver (Sladek et al. 1990). It has a limited tissue distribution in adult animals, being strongly expressed in liver, intestine, and kidney (Sladek et al. 1990). Several earlier experiments suggested that HNF-4 was potentially significant for early development. First, a dedifferentiated hepatoma cell line was defined that had lost expression of both HNF-4 and HNF-1. The introduction of a constitutively expressed HNF-4 cDNA rescued the expression of albumin and fibrinogen plus the endogenous HNF-1 protein, 
but the reverse experiment did not correct HNF-4 or liver-specific gene expression (Kuo et al. 1992). Thus, HNF-4 appears to be upstream of HNF-1. Second, there is a Drosophila homolog of HNF-4, which is present very early as maternal mRNA and persists in terminal structures of the embryo, disappears, and then reappears during organogenesis (Zhong et al. 1993). Finally, we have demonstrated recently that HNF-4 expression in the visceral endoderm of mice begins as early as 4.5 days, during implantation and well before gastrulation (Duncan et al. 1994).

To directly address the developmental role of HNF-4, we have used homologous recombination in embryonic stem (ES) cells to disrupt the gene in mice. Mouse embryos lacking HNF-4 function are grossly abnormal by E8.5 after failing to form mesoderm at the normal time. The cause of this failure may be related to the cell death that begins in the embryonic ectoderm as early as E6.5 during the normal time of mesoderm formation. Expression of marker genes indicates that the primitive streak is retarded by $\sim 24 \mathrm{hr}$, and although mesoderm is generated, few if any normal structures are formed. This early effect was attributable apparently to the important function of HNF-4 in the earliest differentiated endoderm, the visceral endoderm.

\section{Results \\ Targeted disruption of HNF-4 and germ-line transmission}

Like most members of the steroid/thyroid hormone receptor superfamily, the HNF-4 genomic DNA has numerous introns and exons spanning $>30 \mathrm{~kb}$ (Zhong et al. 1993). The second and third exons of the HNF-4 gene, encoding the DNA-binding domain of the protein, were targeted for disnuption (Fig. 1A). A single $\lambda$ bacteriophage clone containing this region had been isolated from a genomic DNA library of 129 mice. We used a positivenegative selection strategy for homologous recombination in ES cells. The targeting vector pPNT (Tybulewicz et al. 1991) includes a neomycin (neo) expression cassette for positive selection and a thymidine kinase $|\mathrm{tk}\rangle$ cassette for negative selection. Both cassettes contain the PGK promoter at the $5^{\prime}$ end and poly(A) addition site at the $3^{\prime}$ end. The neo cassette was flanked by a $6.5-\mathrm{kb}$ fragment of the mouse genomic sequence at the $5^{\prime}$ end and a $1.5-\mathrm{kb}$ fragment at the 3 ' end; the neo cassette was oriented opposite to the direction of HNF-4 transcription. A successful homologous recombination event would replace exons 2 and 3 with the neo gene (Fig. 1A). The final construct was linearized with NotI and elec-

A

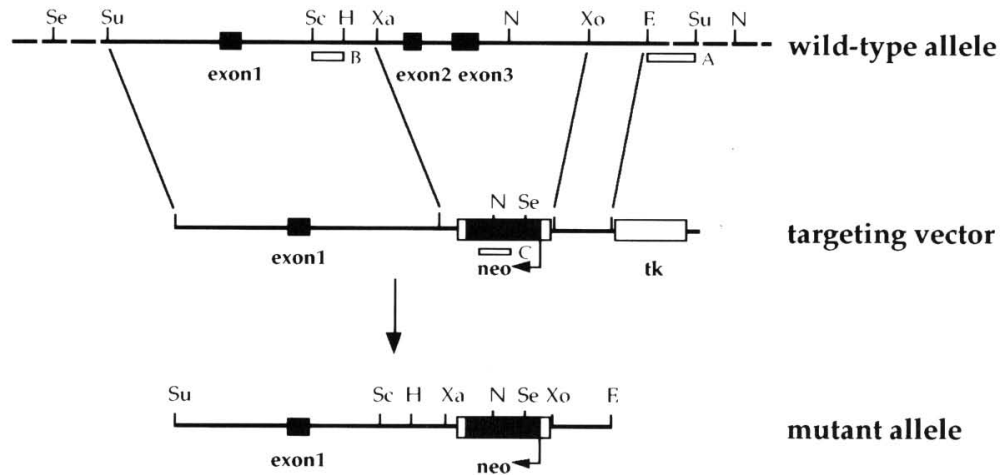

B

$$
\begin{gathered}
\begin{array}{c}
\text { Nco I } \\
\text { (probe A) }
\end{array} \\
\begin{array}{c}
+/++/ m \\
\hline \infty-w \\
-\mathbf{m}
\end{array}
\end{gathered}
$$

Spe I (probe B)

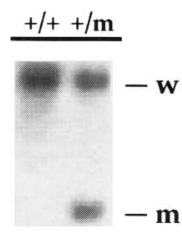

Figure 1. Gene targeting and homologous recombination at the HNF-4 locus and Southern blot analysis. (A) The restriction map of the wild-type genome, targeting vector, and mutant allele is shown. The genomic structure of the HNF-4 gene is presented at the top. The three probes used to determine homologous recombination events are indicated by three open rectangles (A, B, and C). E, H, N, Sc, Su, Se, Xa, and $\mathrm{Xo}$ represent restriction sites for EcoRV, HindIII, NcoI, SacI, Sau3AI, SpeI, Xbal, and $X$ hoI, respectively. $(B)$ Southern blot of homologous recombination events in ES cells. The hybridizing fragment of ES cells $(+1+)$ and clone $2-69(+/ \mathrm{m})$ (described in the text) are 4.5 $\mathrm{kb}$ for the wild-type allele $(\mathrm{w})$ and $3.8 \mathrm{~kb}$ for the mutant allele (m) after $\mathrm{NcoI}$ digestion and using probe $\mathrm{A}$, and $>20 \mathrm{~kb}$ for wild-type allele $(\mathrm{w})$ and $8.5 \mathrm{~kb}$ for mutant allele $(\mathrm{m})$ after SpeI digestion and using probe B. $(C)$ Genotype of E9.5 embryos from heterozygous matings by Southern blot analysis. DNA from embryos was digested with $\mathrm{NcoI}$ using probe A. 
troporated into J1 (Li et al. 1992) and E14 (Hooper et al. 1987) ES cells. Half the samples were used for positive (G-418) and negative (FIAU) selection, and half for positive selection only. Two of 230 colonies scored positive for homologous recombination by Southern blot analysis with a 3 '-end flanking probe. Genomic DNA from wildtype cells gives a $4.5-\mathrm{kb}$ band after $\mathrm{Ncol}$ digestion, whereas the disrupted gene gives a $3.8-\mathrm{kb}$ band. Homologous recombinants at the correct locus were confirmed by use of a 5' probe with SpeI digest (Fig. 1B). A neo probe was used to demonstrate single-copy integration (data not shown).

ES cells from both clones that had undergone homologous recombination were injected into $\mathrm{C} 57 \mathrm{BL} / 6$ blastocysts and one clone (2-69) from Jl cells gave rise to germ-line chimeras ( 2 males). Chimeras were crossed to C57BL/ 6 and $129 / \mathrm{Sv}$ mice to detect the mutant phenotype in a hybrid as well as an inbred genetic background. The genotype of all mice examined was confirmed by Southern blot analysis. Crossing either heterozygous males with wild-type C57BL/ 6 females or heterozygous females with wild-type $\mathrm{C} 57 \mathrm{BL} / 6$ males gave rise to heterozygous offspring that were indistinguishable from their wild-type littermates on both genetic backgrounds. Thus, no overt phenotype was observed with heterozygous mice.

Gross morphological and histological analysis of HNF-4 -1 embryos indicates embryonic lethality and severe disruption of gastrulation

To investigate the phenotype of the HNF-4-1- genotype, heterozygous mice were intercrossed. Among 178 offspring from these matings (hybrid genetic background and isogenous background), no homozygous HNF-4 ${ }^{-1-}$ mice were born, whereas 117 heterozygous HNF-4 $4^{+1-}$ and 61 wild-type HNF-4 ${ }^{+1+}$ offspring were recovered, numbers close to a ratio of $2: 1$, indicating that the HNF-4 $4^{-1-}$ genotype was an embryonic lethal (Table 1 ).

To determine the time of embryonic death and to characterize embryonic morphology, embryos were dissected at different stages during gestation. The genotypes of the embryos were confirmed by either Southern blot analysis (Fig. $1 \mathrm{C}$ ) or polymerase chain reaction (PCR) assay. When embryos were examined at 10.5 days of develop-

Table 1. Genotype of offspring from heterozygous matings

\begin{tabular}{|c|c|c|c|c|}
\hline \multirow[b]{2}{*}{ Breeding } & \multirow{2}{*}{$\begin{array}{l}\text { Number } \\
\text { of litters }\end{array}$} & \multicolumn{3}{|c|}{ Number of each genotype } \\
\hline & & $+1+$ & $+1-$ & $-1-$ \\
\hline $\begin{array}{l}\mathrm{C} 57 \mathrm{BL} / 6 \\
\text { (outbred) }\end{array}$ & 20 & $40(33 \%)$ & $82(67 \%)$ & $0(0 \%)$ \\
\hline $\begin{array}{l}\text { 129/Sv } \\
\quad \text { (inbred) }\end{array}$ & 14 & $21(38 \%)$ & $35 \mid 63 \%)$ & $0(0 \%)$ \\
\hline Total & 34 & $61(34 \%)$ & $117(66 \%)$ & $0\langle 0 \%)$ \\
\hline
\end{tabular}

The genotype is determined by Southern blot analysis, as described in Materials and methods. ment (E10.5), all five HNF-4 $-1-$ mutant embryos recovered consisted primarily of extra embryonic tissues, giant trophoblast cells, parietal endoderm, and a small yolk sac, whereas the embryonic region had degenerated (data not shown). At E6.5, the morphology of HNF-4-1embryos was indistinguishable from that of normal littermates (not shown). When embryos were dissected at E7.5, a set of morphologically abnormal embryos was identified, which corresponded to the HNF-4 ${ }^{-1-}$ genotype (Fig. 2, cf. A and B). Heterozygous embryos showed no differences in morphology from wild-type embryos. The embryonic cylinder of HNF-4 $4^{+1-}$ mutants was small compared with normal littermates $\left(\mathrm{HNF}-4^{+/+}\right.$ and HNF- $4^{+/-}$, but the parietal endoderm appeared to be normal in size, often leading to a large yolk sac cavity (Fig. 2B). Of 59 embryos dissected, 22 displayed this unique abnormal morphology and all of the 22 were confirmed as homozygous mutants /see Table 2, including all data from embryos analyzed by dissection and in situ hybridization). At E8.5, dissected HNF-4 ${ }^{-1-}$ mutant embryos had grown in size compared with $\mathrm{E} 7.5 \mathrm{mu}-$ tant embryos, but were still small when compared with normal E8.5 embryos (Fig. 2, cf. E and F); the embryonic region often appeared distorted in shape. E9.5 homozygous mutant embryos looked very similar to, but somewhat larger than, E8.5 mutant embryos (data not shown).

To characterize further the structure of HNF-4-1mutant embryos, histological studies were carried out. The genotype was determined by in situ hybridization of selected sections to an HNF-4 probe corresponding to the deleted exons; the probe detected expression of HNF-4 mRNA in wild-type and heterozygous embryos but not in homozygous mutant embryos (Fig. 3A-F). All the sections of E7.5 embryos that showed no histological abnormalities, were positive for HNF-4 by in situ hybridization, indicating no detectable effect in heterozygous mutant embryos. This was not the case for homozygous embryos.

At E7.5, normal embryos have a well-defined anteriorposterior axis, and mesoderm generated at the primitive streak has spread through the embryo; in the extraembryonic region the chorion, yolk sac, allantois and amnion are forming (Fig. 2C). However, homozygous HNF-4 $4^{-1-}$ mutant embryos up to E7.5 remained as a two-layered cylinder of ectoderm and endoderm similar to normal embryos at $\mathrm{E} 6.5$ (Figs. $2 \mathrm{D}$ and $3 \mathrm{~F}$; see also $5 \mathrm{~A}$ and $7 \mathrm{C}$, below). By histologic examination, mesodermal cells were not detected lying between the ectoderm and endoderm. The amnion, chorion, and allantois were absent and the embryonic cavities had not expanded normally. The total cell number appeared to be reduced in the mutants, but a quantitative measurement was not carried out. In the HNF-4 $4^{-1}$ embryo of Figure 2D, one side of the epiblast is thicker than the other, suggesting the beginning of a primitive streak. The columnar visceral endoderm overlying the extraembryonic region and the proximal part of the embryonic region appeared well differentiated with numerous microvilli and apical vesicles (Fig. 2D); however, more detailed analyses are re- 


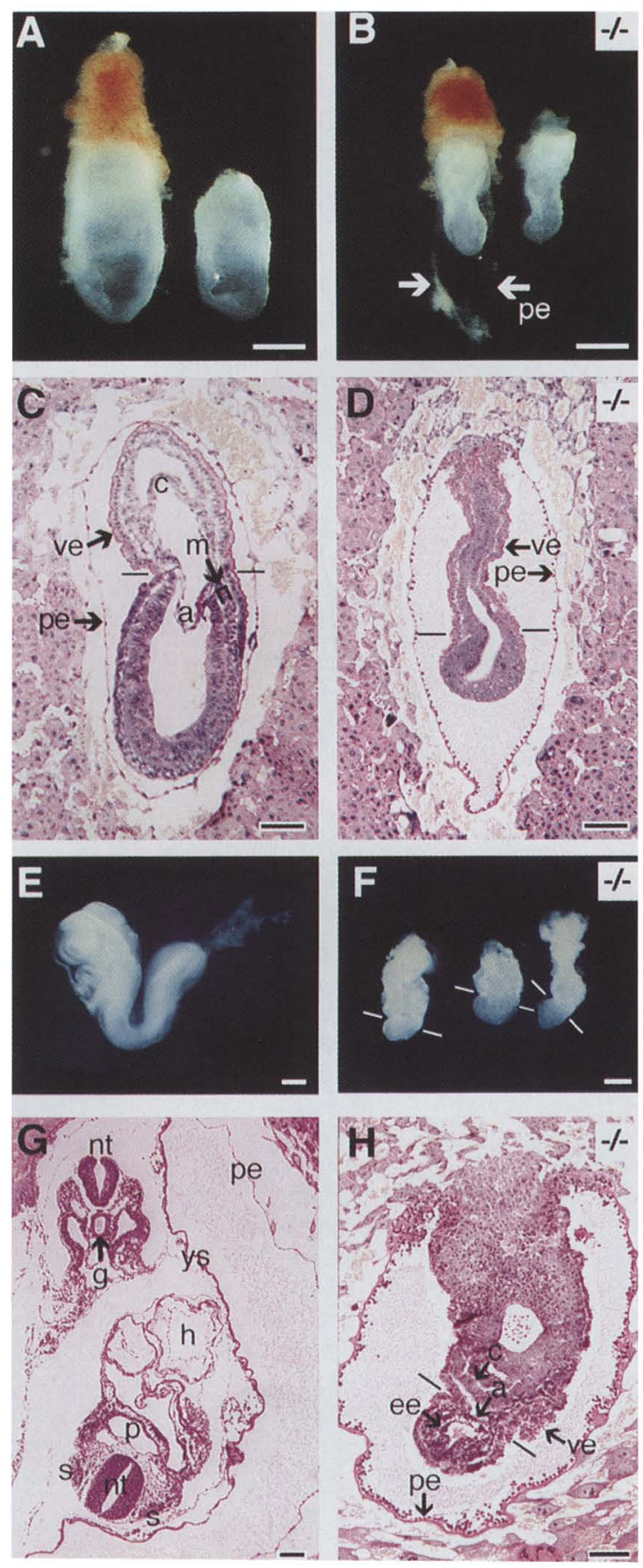

Figure 2. Morphology and histology of E7.5 and E8.5 normal and mutant embryos. (A) Dissected normal embryos at E7.5. The parietal endodermal sac and ectoplacental cone with associated maternal blood were removed from the embryo on the right. (B) Dissected E7.5 HNF- $4^{-1-}$ embryos. The parietal endodermal sac and ectoplacental cone have been removed from the embryo on the right. $(C)$ Approximate sagittal section of an E7.5 normal embryo stained with hematoxylin and periodic acid-Schiff reagent (PAS). Dashes indicate the level of the junction of the embryonic and extraembryonic regions. The columnar visceral endoderm /red staining at its outer border) is apparent covering the extraembryonic and the upper part of the embryonic regions. The amnion and chorion are forming and a mesoderm layer is apparent throughout most of the embryo, indicated on the right side by an arrow and bracket. (D) Approximate sagittal section of an E7.5 HNF- $4^{-1-}$ embryo from the same litter as $C$ stained with hematoxylin and PAS. Dashes indicate the junction between the embryonic and extraembryonic regions. No mesoderm is apparent. $(E)$ Dissected E8.5 normal embryo with well-developed axis, head, and heart structures. Extraembryonic regions have been removed. $(F)$ Dissected E8.5 HNF-4 ${ }^{-1}$ embryo. Dashes indicate approximate border between embryonic and extraembryonic regions. $(G)$ Section of a normal E8.5 embryo stained with hematoxylin and PAS showing normal neural tube, somites, gut, yolk sac, parietal endoderm, and other structures. $(H)$ Section of an E8.5 HNF-4-1- embryo from the same litter as $G$ stained with hematoxylin and PAS. The embryonic region is a small sphere below the dashes. Visceral endoderm covers the embryonic and extraembryonic regions and is folded at the arrow. The layer of parietal endoderm and associated Reichert's membrane (red) look much thicker than normal probably because of a lack of expansion of the embryo. A rudimentary amnion and chorion may be present as indicated; cf. with $C$. A necrotic zone is apparent in the middle of the extraembryonic region. (a) Amnion or presumptive amnion; (c) chorion or presumptive chorion; (ee) embryonic ectoderm; $(\mathrm{g})$ gut; $(\mathrm{h})$ heart; $(\mathrm{m})$ mesoderm; $(\mathrm{nt})$ neural tube; $(\mathrm{p})$ pharynx; (pe) parietal endoderm; (s) somites; (ve) visceral endoderm; (ys) yolk sac. Bar, $250 \mu \mathrm{m}\langle A, B, E, F\rangle ; 100 \mu \mathrm{m}\langle C, D, G, H)$.

quired to determine whether subtle abnormalities in cell and organelle morphology may be present.

Histological analysis of homozygous mutant embryos at E8.5 showed embryonic development to be severely disrupted. Normal littermates had developed large head folds and axial structures, including a notochord and a few somites (Fig. 2G). In homozygous mutant embryos, the embryonic portion was a relatively small sphere or ovoid structure in the distal region (Fig. $2 \mathrm{H}$ ). The embryonic ectoderm varied from a thin sphere at the center to a thicker columnar epithelial tube (Figs. 2H, 4D, and $5 \mathrm{H}, \mathrm{I})$. Some putative mesoderm had appeared in the embryonic region by E8.5 in mutant embryos, forming a third layer between ectoderm and endoderm, but none of the structures of normal embryos could be identified. The extraembryonic region was a large mass of tissues with relatively small cavities, and structures were present that could represent a rudimentary amnion, chorion, and yolk sac. Many normal giant trophoblast cells were seen. Overall, the lack of expansion of embry- 
Chen et al.

Table 2. Genotype of embryos from heterozygous matings

\begin{tabular}{lcc}
\hline & \multicolumn{2}{c}{ Number of genotype } \\
\cline { 2 - 3 } Age & $+/-,+/-$ & $-/-$ \\
\hline E9.5 & 15 & 5 \\
E8.5 & 39 & 12 \\
E7.5 & 51 & 25 \\
E6.5 & 20 & 11 \\
\hline
\end{tabular}

The genotype is determined by Southern blot analysis, PCR assay, or in situ hybridization as described in Materials and methods. Because in situ hybridization can only distinguish homozygotes from wild type and heterozygotes, wild-type and heterozygote numbers are combined. Resorbed embryos are not included.

onic layers evident at E7.5 was even more obvious at E8.5. Thus, the gross phenotype of HNF- $4^{-1-}$ mutant embryos can be described as a retarded and abnormal gastrulation process, associated with decreased growth.
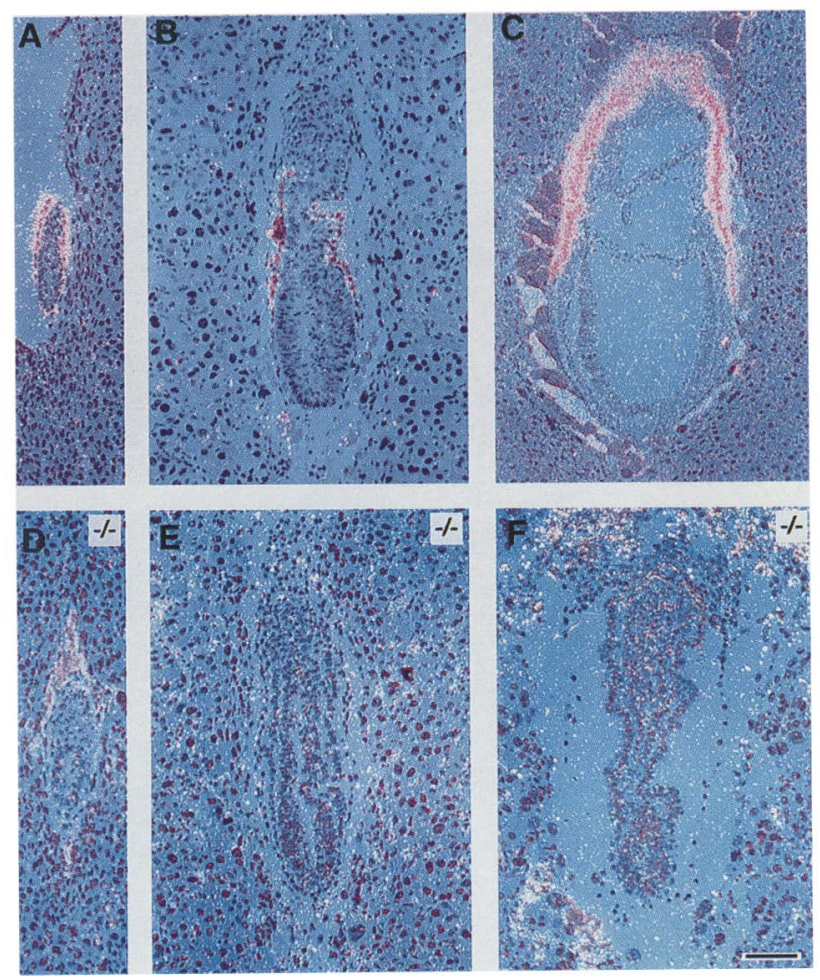

Figure 3. Genotyping of sectioned embryos by in situ hybridization. A probe to the HNF-4 exons deleted in mutant mice was used. Photos are combined bright field/dark field, where dense labeling appears red and light labeling appears white. Distal regions of the embryo are toward the bottom in $A-F .(A)$ E5.5 normal embryo. Visceral endoderm around the embryo is labeled. (B) E6.5 normal embryo. Columnar visceral endoderm around the extraembryonic and upper embryonic regions is labeled. $(C)$ E7.5 normal embryo. Columnar visceral endoderm is labeled. $(D)$ E5.5 HNF-4 ${ }^{-1-}$ embryo. $(E)$ E6.5 HNF-4 ${ }^{-1-}$ embryo. $(F)$ E7.5 HNF-4 ${ }^{-1-}$ embryo. Bar, $100 \mu \mathrm{m}(A, B, D, E, F) ; 125$ $\mu \mathrm{m}(C)$.

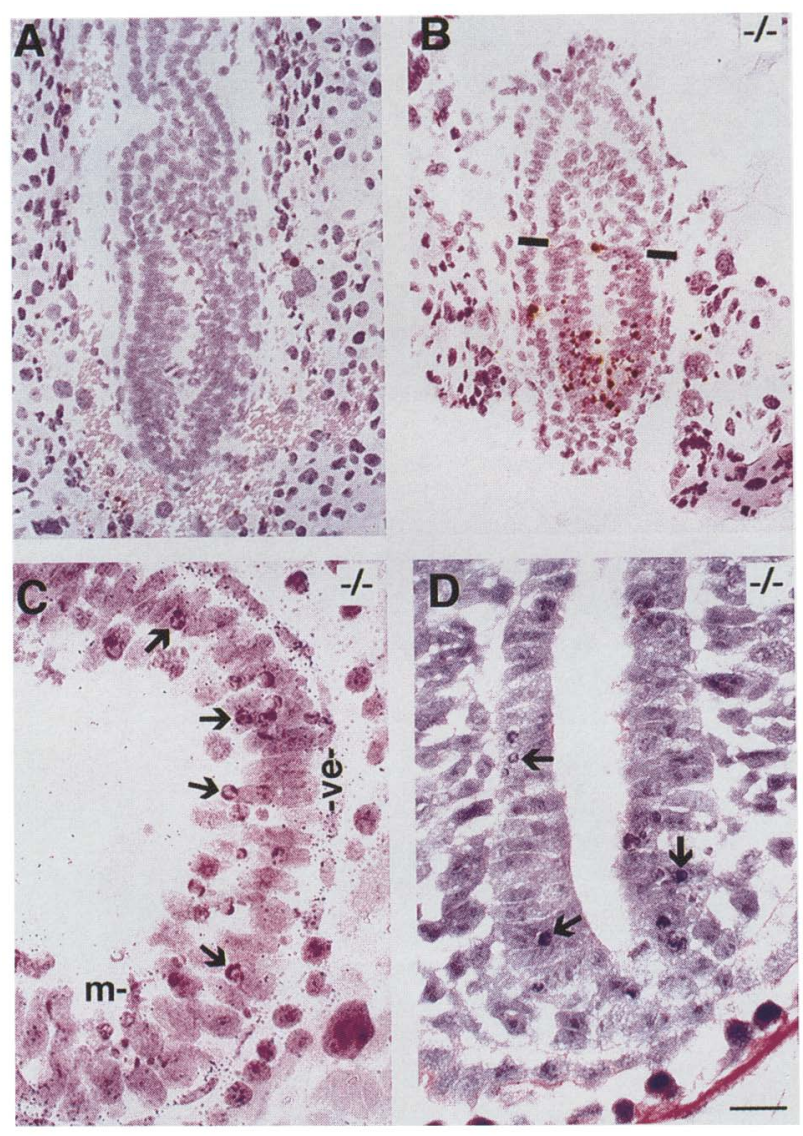

Figure 4. Cell death observed in sections of normal and mutant embryos. (A) E6.5 normal embryo subjected to the TUNEL reaction; $(B)$ E6.5 HNF-4 $4^{-1-}$ embryo subjected to the TUNEL reaction. Brown-stained nuclei indicate end incorporation in DNA. Dashes indicate the junction between the embryonic and extraembryonic regions. (C) E7.5 HNF-4 ${ }^{-1-}$ embryo showing the distal region of embryonic ectoderm. In situ hybridization with an HNF- $3 \beta$ probe was followed by staining with hematoxylin and eosin; grains are observed over the visceral endoderm. Arrows indicate some of the many pyknotic nuclei in the embryonic ectoderm. (m) Mitotic figure. (D) E8.5 HNF-4 ${ }^{-1-} \mathrm{em}$ bryo. Section stained with hemotoxylin and PAS. A tube of embryonic ectoderm occupies most of the field, and arrows indicate some of its pyknotic nuclei. Bar, $60 \mu \mathrm{m}(A, B) ; 20 \mu \mathrm{m}$ $(C, D)$.

\section{Cell death appears in embryonic ectoderm} of homozygous mutant embryos at the time of normal gastrulation

Although the homozygous mutant embryos at E7.5 displayed a distinct morphology and histology, mutant embryos at E5.5 appeared normal (Fig. 3, cf. A and D). At E6.5 when normal embryos are at prestreak or early primitive streak stages, mutant embryos were essentially normal in overall morphology except that they were often smaller (Fig. 3, cf. B and E). However, dying cells marked by pyknotic nuclei were clearly present at a higher frequency in the embryonic ectoderm of mutant than of normal embryos. To characterize these presump- 

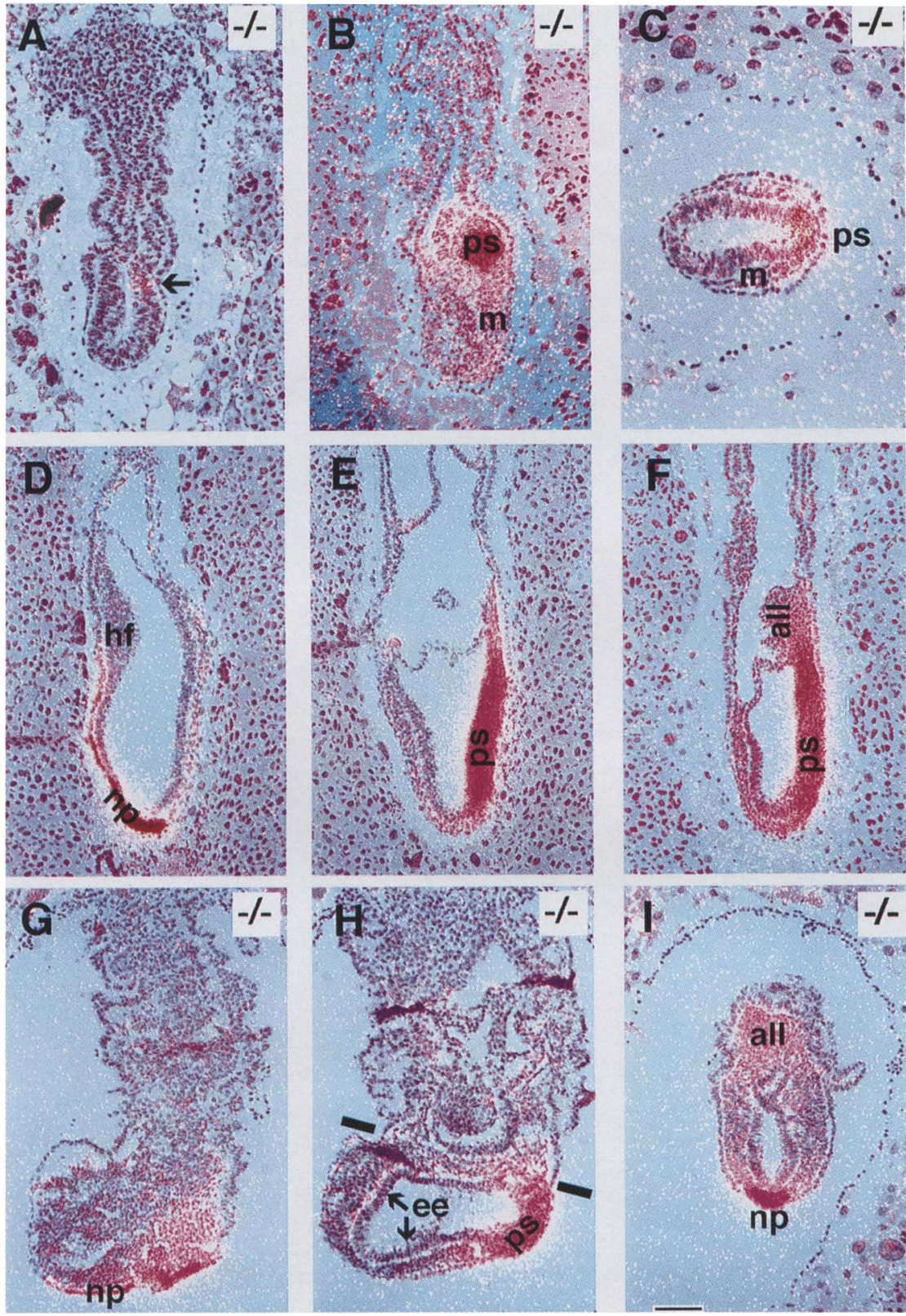

Figure 5. Expression of $T$ in normal and mutant embryos examined by in situ hybridization. Posterior is to the right, and all panels show approximate sagittal sections except for $C$ and $I$. (A) E7.5 HNF-4-1- embryo. Low expression is seen in one region of proximal embryonic ectoderm (arrow). (B) E7.5-E8.0 HNF-4 ${ }^{-1-}$ embryo. High expression is present in one region indicating a primitive streak in the proximal region of the embryo. Mesodermal cells have appeared between the ectoderm and endoderm. $(C)$ E8.0 HNF-4 $4^{-1-}$ mutant embryo. Cross section showing labeling of the primitive streak and presence of lateral mesoderm. (D) E7.5 normal embryo showing strong label in the midline notochordal plate extending from the distal tip of the embryo up the anterior side. (E) Nearby section of the same embryo shown in $D$ with strong labeling in the primitive streak extending along the posterior side. $\langle F\rangle$ E7.5 normal embryo showing light labeling extending up from the strongly labeled primitive streak into the lower half of the allantois. $(G)$ E8.5 $\mathrm{HNF}^{-4^{-/}}$embryo showing a notochordal plate-like structure extending forward from the primitive streak (cf. with $D)$. $(H)$ Nearby section of the same E8.5 HNF-4 ${ }^{-1}$ embryo showing strong labeling of a primitive streak-like structure /cf. with $E \mid$. Dashes indicate the boundary between the embryonic and extraembryonic regions. (I) Frontal section of an E8.5 HNF-4 ${ }^{-1-}$ embryo showing strong labeling of the notochordal plate and light labeling of cells in the extraembryonic region interpreted as allantoic mesoderm. (all) Allantois or presumptive allantois; (ee) embryonic ecto$\operatorname{derm}_{i}(\mathrm{hf})$ early head fold; (m) mesoderm; (np) notochordal plate; (ps) primitive streak. Bar, $100 \mu \mathrm{m}$. tive dead or dying cells, the TUNEL (TdT-mediated dUTP-biotin nick end labeling) reaction was carried out on embryo sections (Gavrieli et al. 1992). This method detects free ends of DNA generated during apoptosis by staining nuclei that have incorporated biotinylated dUTP during incubation with terminal transferase. In all nine mutants examined there was a significantly greater number of strongly stained nuclei than in any of the 15 normal embryos examined. Representative examples of normal and mutant embryos are shown in Figure 4, A and B. Few dying cells were observed in the extraembryonic region. The dying cells were scattered throughout the embryonic ectoderm but were often present at a higher concentration in the distal half; some mitotic fig- ures were also evident. At both E7.5 and E8.5, the embryonic ectoderm of mutant embryos continued to show a relatively high level of cell death; mesoderm and endoderm showed little cell death (Fig. 4C,D). Because the ectodermal cells in the posterior region of the embryo are destined to give rise to mesoderm during gastrulation, cell death in the ectoderm may foreshadow later failure in development.

\section{Expression patterns of marker genes reveals delayed} formation of a primitive streak and abnormal mesoderm development in HNF-4 ${ }^{-1-}$ mutant embryos

To determine whether a primitive streak was formed and 
to characterize mesoderm development and differentiation in mutant embryos, the expression patterns of the marker genes Brachyury $(T)$, HNF-3 $\beta$, and Mox-1 were analyzed. $T$ is one of the earliest markers for mesodermal cells. It is first detected in premesoderm cells of the primitive ectoderm at the onset of gastrulation at 6.5 days; it is then expressed in all layers of the primitive streak, in the node, and later in the notochordal plate extending anteriorly in the midline from the node (Wilkinson et al. 1990; Herrmann 1991; Beddington et al. 1992; Kispert and Herrmann 1994|. Intense labeling of the streak and notochordal plate, and low labeling of the basal half of the allantois is shown for normal embryos at E7.5 in Figure 5, D-F. However, in E7-7.5 homozygous mutant embryos, $T$ expression was only detected in a small cluster of cells in the primitive ectoderm (Fig. 5A), similar to the expression pattern of $T$ in normal E6.5 embryos (Beddington et al. 1992; Kispert and Herrmann 1994). This cluster presumably marks the posterior side of the embryo. In mutant embryos around E8, expression extended to a large cluster of cells in the thickened ectoderm (Fig. 5B,C). The general configuration of $T$-expressing cells resembled that of a primitive streak. Some presumed mesodermal cells were observed as a distinct layer extending out laterally between ectoderm and endoderm and distally toward the tip of the embryo, as well as proximally into the extraembryonic region. Expression of $T$ in these cells declined to undetectable levels in the more distal mesoderm as in normal embryos. In E88.5 mutant embryos, cells expressing $T$ formed a distinct structure resembling a short primitive streak. This region consisted of strongly labeled ectodermal cells and also ingressing presumed mesodermal cells (Fig. 5G-I). At E8.5, a strongly labeled structure was present in the midline of the mesendoderm layer extending anteriorly from the primitive streak and lying below unlabeled ectoderm (Fig. 5G); we interpret this as a rudimentary notochordal plate. In the extraembryonic region a mass of lightly labeled cells resembling allantoic mesoderm was found above the abnormal primitive streak region (Fig. 5I). Thus, overall anterior-posterior axial organization of the embryo had occurred, but few recognizable structures had developed.

HNF-3 $\beta$, a winged helix transcription factor (Clark et al. 1993; Lai et al. 1993), is expressed in the primitive streak and node during early development (Ang et al. 1993; Monaghan et al. 1993; Ruiz i Altaba et al. 1993; Sasaki and Hogan 1993). In normal embryos around E6.5, expression of HNF- $3 \beta$ was first seen in one region of the embryonic ectoderm marking the posterior side (Fig. 6A). In early streak embryos, HNF- $3 \beta$ expression was strong in the anterior portion of the primitive streak, including the adjacent endoderm, and was also found in the visceral and parietal endoderm around the entire embryo (Fig. 6B). In HNF-4 ${ }^{-1}$ mutant embryos, expression of HNF-3 $\beta$ appeared at about E6.5 in visceral and parietal

Figure 6. Expression of HNF-3 $\beta$ in normal and mutant embryos. Posterior is to the right and all panels show approximate sagittal sections except for $G$. (A) E6.5 normal embryo. Low expression is seen in a group of cells in the posterior embryonic ectoderm and adjacent endoderm (arrow). (B) Slightly later normal embryo collected at E6.5. High expression is seen in the region of the anterior primitive streak and throughout the visceral and parietal endoderm. (C) E7.5 normal embryo. (D) E6.5 HNF-4 $4^{-1}$ embryo. Little label is seen. Nuclei stained by the TUNEL reaction are faintly visible in the embryonic ectoderm. (E) Slightly later HNF-4 $4^{-1-}$ embryo collected at E6.5. Expression is seen throughout the visceral and parietal endoderm. $(F)$ E7.5 $\mathrm{HNF}^{-4^{-1}}$ embryo. Expression is seen throughout the visceral and parietal endoderm and in a small region in the embryonic ectoderm (arrow). $(G)$ Cross section of an E7.5 HNF-4 ${ }^{-1}$ embryo showing expression on one side of the embryonic ectoderm and in visceral and parietal endoderm. Bar, $100 \mu \mathrm{m}$.
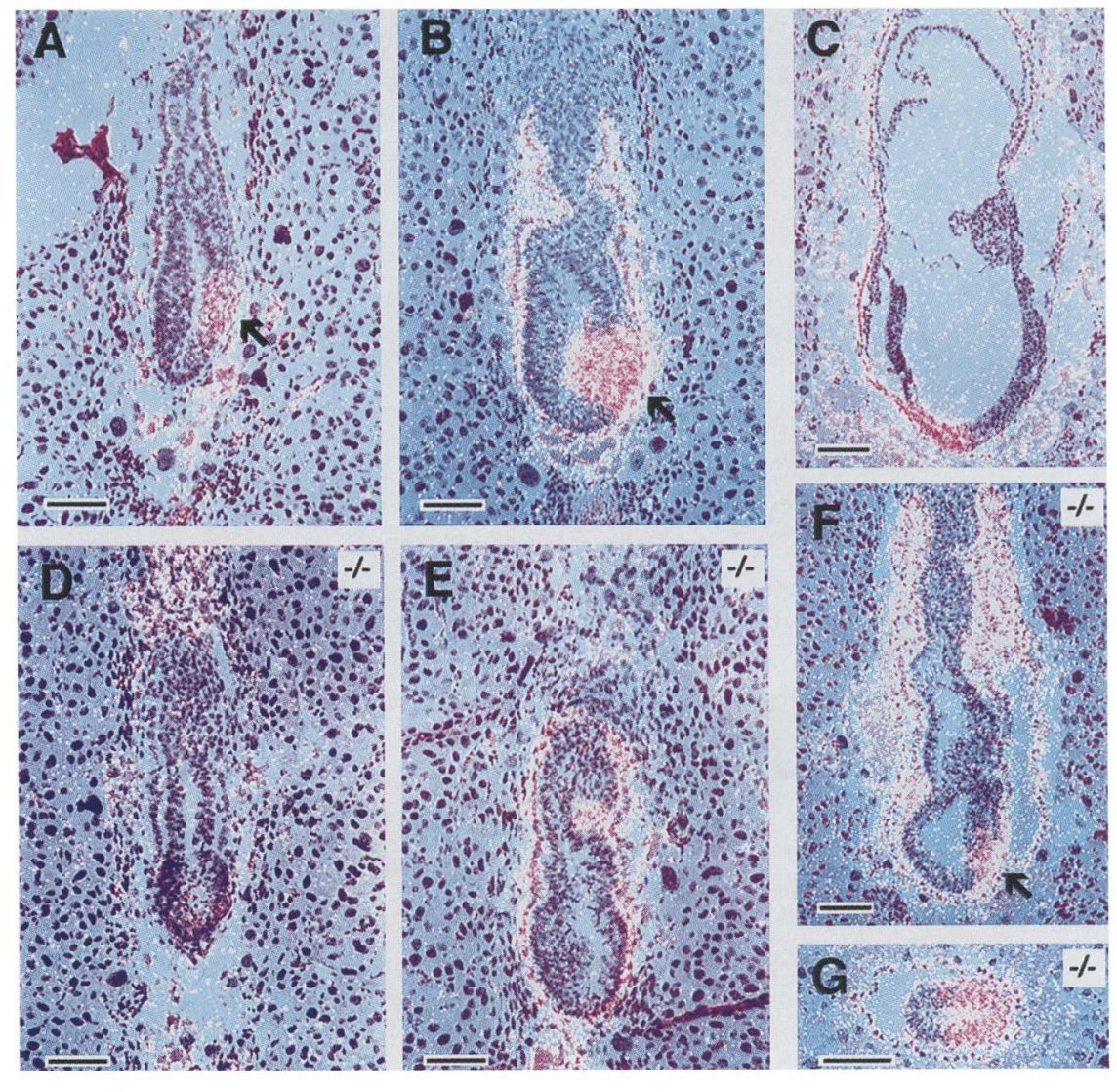
endoderm as in normal embryos; however, little or no expression was seen in the embryonic ectoderm (Fig. $6 \mathrm{D}, \mathrm{E})$. At E7.5, mutant embryos expressed HNF-3 $\beta$ in a pattern similar to normal embryos at E6.5, that is, there was expression in a region of embryonic ectoderm as well as expression in visceral and parietal endoderm surrounding the whole embryo (Fig. $6 \mathrm{~F}, \mathrm{G}$ ). Thus, the expression of both $T$ and HNF-3 $\beta$ indicate that a primitive streak and node may be formed in mutant embryos but are delayed by $\sim 24 \mathrm{hr}$.

Mox-1, a homeo box gene family member, is expressed primarily in presomitic mesodermal cells during gastrulation (Candia et al. 1992). In normal embryos at E7.5, Mox-1 expression was limited to posterior mesoderm and was not found in ectoderm, endoderm, or neural tissue (Fig. 7A). At later stages, MoX-1 was expressed in presomitic mesoderm (Fig. 7B), in somites, and at a lower level in lateral plate mesoderm. In the HNF-4 $4^{-1-} \mathrm{mu}-$ tant embryos, there was no detectable level of Mox-1 expression during the period from E7.5 to E8.5 (Fig. $7 \mathrm{C}, \mathrm{D}$ ), suggesting that no mesodermal cells progressed to presomitic cells.
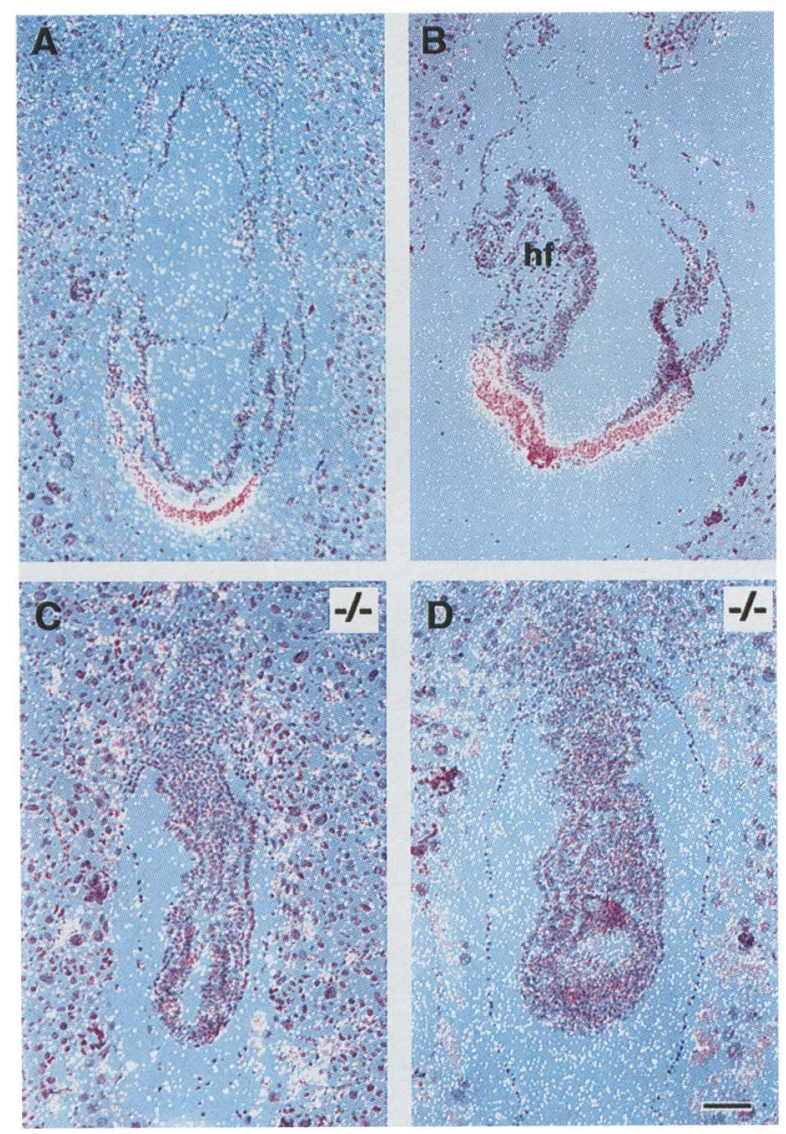

Figure 7. Expression of Mox-1 in normal and mutant embryos. (A) A parasagittal section of an E7.5 normal embryo just lateral to the midline. Expression is seen in the paraxial mesoderm. $(B)$ A parasagittal section of an E8.5 embryo. Expression is seen in paraxial mesoderm. (hf) Headfold. $(C)$ E7.5 HNF-4-1- embryo. (D) E8.5 HNF-4 H $^{-}$embryo. Bar, $100 \mu \mathrm{m}$.

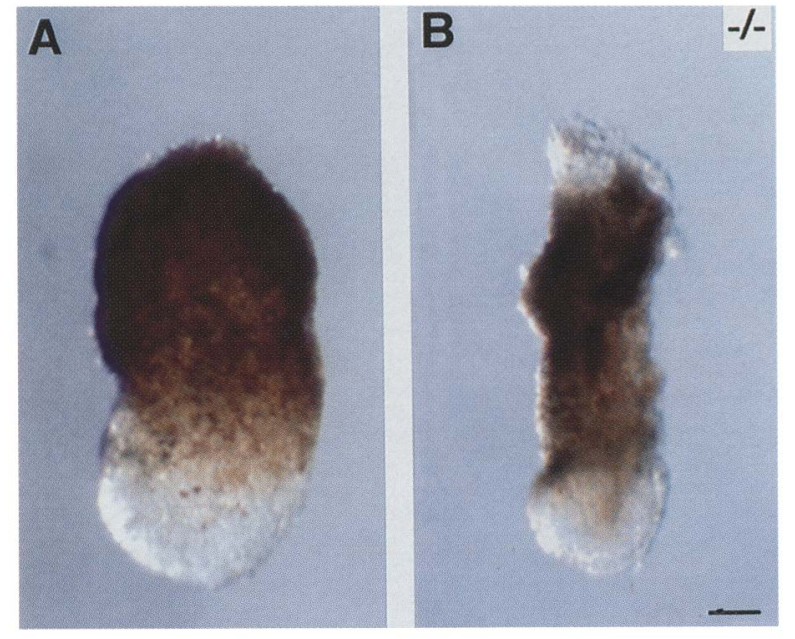

Figure 8. Endocytosis by normal and HNF-4 $4^{-1-}$ mutant E7.5 embryos. Brown stain indicates endocytotic uptake of HRP into apical vesicles of the visceral endoderm (confirmed in sections). (A) Normal embryo; $(B)$ HNF-4 $4^{-1-}$ embryo. Bar, $100 \mu \mathrm{m}$.

The visceral endoderm of HNF-4 ${ }^{-1-}$ mutant embryos is active in endocytosis

By in situ hybridization, HNF-4 expression during gastrulation was observed only in the visceral endoderm (Fig. 3A-C; Duncan et al. 1994), which envelops the embryo with an epithelium containing tight junctions. Small molecule transport and transcytosis serve to deliver nutrients and proteins to the embryo. The columnar cells of the visceral endoderm contain numerous apical microvilli and large apical vacuoles, indicating very active endocytosis. To compare endocytic activity of normal and HNF-4 $4^{-1-}$ mutants, embryos from heterozygous crosses were dissected at E7.5 and incubated in a medium containing horseradish peroxidase, followed by staining with diaminobenzidine. Both the normal and HNF- $4^{-1-}$ mutant embryos gave strong staining in the visceral endoderm located over the extraembryonic and the upper part of the embryonic regions (Fig. 8A,B). The squamous endoderm over the distal portion of the embryo showed little stain. This result suggests that endocytic activity is similar in normal and $\mathrm{HNF}^{-4^{-1-}} \mathrm{mu}-$ tant embryos.

\section{Discussion}

Homozygous mutant HNF-4 embryos die before E10.5 and display a dramatic phenotype in which gastrulation is severely delayed and disrupted. The first cellular abnormality in HNF-4 $4^{-1-}$ embryos is increased cell death in the embryonic ectoderm at E6.5, the time when generation of mesoderm from ectoderm normally begins. As development progresses, this increased cell death remains obvious specifically in the embryonic ectoderm. From in situ hybridization analysis in early embryos we know that HNF-4 expression can only be detected in the visceral endoderm (Duncan et al. 1994), and so the pri- 
mary defect in the mutants presumably results from disruption of HNF-4 in this tissue. Therefore, the development of the embryonic ectoderm appears to be dependent on the function of the visceral endoderm. However, we cannot totally rule out that the expression of HNF-4 in the ectoderm is below the level of detection, and so it is possible that the absence of HNF-4 in the ectoderm offers a subtle contribution to the homozygous mutant phenotype.

The columnar visceral endoderm cells of mutant embryos appeared to be histologically normal and active in endocytosis; therefore, HNF-4 is not necessary for their determination. By E5.5, the visceral endoderm forms a tight epithelial barrier around the rodent embryo mediating exchange with external maternal blood and decidual products (Parr and Parr 1986; Jollie 1990). The visceral endoderm later gives rise to the endodermal cells of the yolk sac; these cells are necessary for normal development of rodent embryos as shown by the effects of exposure to various antivisceral endoderm agents (Beckman et al. 1990). The yolk sac endoderm, like hepatocytes from which HNF-4 was originally isolated, is active in secretion, transcytosis, and digestion (Jollie 1990). The yolk sac secretes many proteins that hepatocytes also produce (Thomas et al. 1990). Many of these proteins have demonstrated HNF-4-binding sites in their regulatory regions (Sladek 1994). In addition, some proteins involved in transport and digestion may also be affected; thus, provision of both a set of transported protein factors and low-molecular-weight nutritional products may be reduced in the mutants. HNF-4 also controls the expression of HNF-1 (Kuo et al. 1992), another transcription factor regulating the expression of many other proteins; this cascade of regulation could lead to a change in the level of many additional proteins. Therefore, the most likely interpretation for the mutant phenotype is that the combined effect of the decrease in provision of several to many molecules results in cell death within the embryonic ectoderm. This cell death may be attributable to the absence of specific factors required by the embryonic ectoderm. Support of the survival of distinct groups of cells by specific factors may be a general phenomenon in development (Raff 1992). Alternatively the cell death in the embryonic endoderm could be attributable to a higher requirement for more general factors as a result of the rapid rate of cell division within the embryonic ectoderm. This latter possibility is made less likely by the observation that the emerging mesoderm displays little cell death. Abnormalities in the extraembryonic ectoderm observed at E8.5 may also be attributable to decreased provision of factors and molecules by the visceral endoderm or may be secondary to the delayed and abnormal production of extraembryonic mesoderm.

The visceral endoderm may be compared with the liver, kidney, and intestine, where HNF-4 is highy expressed in the adult. All of these tissues are highly developed transporting and secretory epithelia. Thus, it is likely that the same transcription factor involved in expression of specific genes in the three adult tissues may be involved in expressing an overlapping set of genes in the visceral endoderm. The very early effect of the HNF-4 mutation is apparently the result of the dependence of the embryo on the normal function of this epithelium in the embryo.

A striking element of the HNF-4 ${ }^{-1-}$ phenotype was the $\sim 24-\mathrm{hr}$ delay in mesoderm differentiation and in the onset of expression of $T$ and HNF-3 $\beta$, both early markers for cells in the primitive streak and node. The delay in production of mesoderm may be attributable to decreased responsiveness within the epiblast (secondary to decreased provision of factors by the visceral endoderm) and/or to the fact that one or more of the affected factors normally participates in mesoderm induction. Although delayed, the initial expression pattern of these mRNAs was similar to that in normal E6.5 embryos; the expressing cells occupied a distinct zone at one side of the embryonic cylinder, and presumptive mesodermal cells could be seen spreading out from this region between ectoderm and endoderm. As development continued, an incipient notochordal plate was observed consisting of cells strongly expressing $T$ extending in the midline anteriorly from the primitive streak, again $\sim 24 \mathrm{hr}$ later than normal. Apparently, the embryonic ectoderm could mount some semblance of mesodermal development and normal gastrulation. Although several kinds of mesodermal cells may be generated, no presomitic mesoderm was detected as evidenced by lack of expression of Mox-1, an early marker for this tissue. In normal development, expression of Mox-1 follows closely the decline of $T$ expression in presomitic mesoderm; development is blocked at this step in HNF-4 ${ }^{-1-}$ mutant embryos. Overall, the expression patterns of $T$ and HNF-3 $\beta$ in HNF- $4^{-1-}$ mutant embryos showed that the first steps in the establishment of a normal anterior-posterior axis with axial structures can occur in mutant embryos, but further development was not observed.

Approximately 12 loci or genes have been identified, which are required for normal development during gastrulation and before somite formation (E6-E8) (Green 1989; Holdener-Kenny et al. 1992). Of these, the phenotype of the recessive lethal mutation $t^{w 5}$ is most similar to that of HNF-4 homozygotes; $t^{\text {w5 }}$ is one of several embryonic lethals found in different $t$ haplotypes of the $t$ complex on chromosome 17 (Bennett 1975; Silver 1985). In $t^{\mathrm{w} 5} / t^{\mathrm{w} 5}$ embryos gastrulation is delayed, pyknosis is evident in the embryonic ectoderm, and the visceral endoderm does not appear to be fully differentiated (Bennett and Dunn 1958). However, the molecular basis of the mutation is still unknown (see Ebersole et al. 1992).

Several genes have been characterized that affect development at the time of gastrulation. The gene fugl (DeGregori et al. 1994), whose expression is ubiquitous and increases just before gastrulation, encodes a protein homologous to RNAl in yeast. The homozygous mutant embryos are small at day E6.5 and E7.5, with no obvious mesoderm, and are resorbed by E8.5 (DeGregori et al. 1994). Another gene, $H \beta 58$, encodes a novel gene product that is expressed in embryonic ectoderm, extraembryonic ectoderm, and prominently in visceral endoderm 
during gastrulation (Lee et al. 1992). Homozygous mutants for $H \beta 58$ are delayed during gastrulation with an underdeveloped embryonic ectoderm but reach the early somite stage by E9.5 (Radice et al. 1991). A third gene, nodal, encodes a factor in the TGF- $\beta$ superfamily (Zhou et al. 1993) that is expressed at the onset of gastrulation in the posterior embryonic ectoderm and later concentrates in cells around the periphery of the node (Zhou et al. 1993). Homozygous mutants fail to form mesoderm and exhibit a folding of the ectoderm and endoderm layers with cell death in the embryonic ectoderm (Robertson et al. 1991; Iannaccone et al. 1992).

In conclusion, the severe disturbance of the development of embryos lacking transcription factor HNF-4 function is the first direct demonstration that a gene expressed only in visceral endoderm during early development has functional importance in embryonic ectodermal and ectomesodermal differentiation.

\section{Materials and methods \\ Construction of target vector}

A genomic DNA library from 129 mice was screened for the HNF-4 gene. One positive clone was analyzed by restriction mapping and was confirmed to contain exons 1,2 , and 3 by hybridization with the exon 1-specific oligonucleotide $\left(5^{\prime}\right.$-CTGCACATTTTCAAACTCCAG), exon 2-specific oligonucleotide probe (5'-GGCCCGATCGCCACAGATGGC), and exon 3-specific oligonucletoide probe $15^{\prime}$-AAGAGGAACCAGTGTCGTTAC) but not with exon 4-specific oligonucleotide probe (5'-ATCCCGCTCATTTTGGACGG). The targeting vector, pPNT (Tybulewicz et al. 1992), contains a neo cassette for positive selection and a tk cassette for negative selection. A NotI-XbaI fragment of $6.5 \mathrm{~kb}$ from the $5^{\prime}$-end of the clone was inserted into the pPNT vector EcoRI and $A s p 718$ sites by the filling in of the NotI site and conversion of the $X b a I$ site to an Asp718 site. The XhoI-EcoRV fragment of $1.4 \mathrm{~kb}$ from the 3' end of the clone was inserted into the pPNT vector XhoI and NotI sites by conversion of the EcoRV site to a NotI site.

\section{Transfection and selection of ES cells}

The targeting vector linearized by NotI was electroporated into Il (Li et al. 1992) or E14 (Hooper et al. 1987) ES cells (from strain $129)$ at $200 \mathrm{~V}$ and $800 \mu \mathrm{F}$. Stable colonies were selected with 350 $\mathrm{mg} / \mathrm{ml}$ of G-418 and $0.2 \mu \mathrm{M}$ FIAU in ES cell media (Robertson 1987). Nine days after transfection, single colonies were picked into 96-well plates for an additional 3-5 days in culture, and expanded into 24-well plates. Half of each clone in the 24-well plates was used for Southern blot analysis.

\section{Genomic Southern blot analysis and PCR assay}

Genomic DNA of ES cells and of tail tip from mice was isolated as described by Plump et al. (1992). For embryo DNA, embryos were dissected from timed pregnant mice (day of plug = E0.5) into cold PBS and photographed, and genomic DNA of the whole embryo was prepared according to the same method as tail tip DNA. To determine genotype by Southern blot analysis (Plump et al. 1992), DNAs were digested by NcoI. To genotype embryos by PCR, three oligonucleotides were designed. One was in the 3'-flanking region from targeting vector as 4-clR (5'-GATCCTCAAGGTTAGCCGGCCC), the other one was in
HNF-4 gene as 4-c3 (5'-CTAGGGCTAGTGAAGAGAGATC$\mathrm{TAC})$, and the third one was in the neo gene as 4-c2R (5'-GGACCCACCCCTTCCCAGCCTC). The HNF-4 PCR oligonucleotides 4-clR and 4-c3 were involved, as well as the neo PCR oligonucleotides 4-clR and 4-c2R. All reactions were carried through 30 cycles of denaturing at $94^{\circ} \mathrm{C}$ for $1 \mathrm{~min}$, annealing at $69^{\circ} \mathrm{C}$ for $1 \mathrm{~min}$, and extending at $72^{\circ} \mathrm{C}$ for $1 \mathrm{~min}$ and another 3 sec.

\section{In situ hybridization}

A sequence containing exons 2 and 3 was amplified by PCR with exon $25^{\prime}$ primer (5'-ACACGTCCCCATCTGAAGGTG) and exon $33^{\prime}$-R primer (5'-CTTCCTTCTTCATGCCAGCCC) from a mouse HNF-4 cDNA that contained nucleotides 147416 corresponding to rat cDNA (Sladek et al. 1990). The PCR fragment was cloned into a $\mathrm{T}$-vector that was generated by digesting Bluescript KS (Stratagene) with EcoRV and adding dT according to Marchuk et al. (1990). This plasmid, p4-is, was digested with EcoRI or ClaI and transcribed with $\mathrm{T} 3$ or $\mathrm{T} 7$ and $\left[{ }^{33} \mathrm{P}\right] \mathrm{UTP}$ in vitro for sense or antisense probes.

Probes of Brachyury, Mox-1, and HNF-3 $\beta$ for in situ hybridization were prepared from plasmids by the same method as for HNF-4. Plasmid pME68s that covers 300 bp of Brachyury cDNA (Herrman et al. 1990) was digested with either XhoI or BamHI and transcribed with either $\mathrm{T} 3$ or $\mathrm{T} 7$ for sense or antisense probes. Plasmid $\Delta M o x-1$ that contained a 70 -bp fragment of Mox-1 cDNA (Candia et al. 1992) inserted in Bluescript PstI and EcoRI sites was digested with either EcoRI or PstI and transcribed with either T7 or T3 for sense or antisense probes. Plasmid K2R1 that includes HNF-3 $\beta$ cDNA (Ruiz et al. 1993) was digested with either NotI or HindIII and transcribed with T7 or T3 for sense and antisense probes.

Sections for in situ hybridization were prepared as described by Duncan et al. (1994). Sections hybridized with sense probes for HNF-4, Brachyury, Mox-1, and HNF-3 $\beta$ showed no signal above background, and sections hybridized with antisense probe of HNF-4 gave no signal above background for HNF-4 ${ }^{-1-}$ mutant embryos. Slides were photographed by double exposure; one exposure was bright field, and one was dark field with a red filter.

\section{TUNEL reaction for visualization of cell death in situ}

The TUNEL reaction to detect incorporation of biotinylated dUTP mediated by terminal transferase was carried out on sectioned embryos as described (Gavrieli et al. 1992), except that the peroxidase inactivation was with $0.1 \% \mathrm{H}_{2} \mathrm{O}_{2}$ for $15 \mathrm{~min}$, biotin-16-dUTP was used at a final concentration of $5 \mu \mathrm{M}$, instead of extra-avidin peroxidase, the Vectastain $A B C$ reagent from Vector Laboratories was used according to their instructions, and diaminobenzidine was used as a peroxidase substrate.

\section{Uptake of horseradish peroxidase}

Embryos from a cross of heterozygous HNF-4 mutant parents were dissected at E7.5, incubated for $1 \mathrm{hr}$ in $50 \%$ rat serum, $25 \%$ mouse serum, and 25\% Dulbecco's modified Eagle medium, then for $5 \mathrm{~min}$ in medium plus horseradish peroxidase (HPR) $(2$ $\mathrm{mg} / \mathrm{ml}$ ). Embryos were fixed and processed as described (Kadokawa et al. 1987). After photography, embryos were embedded in paraffin, sectioned, and subjected to in situ hybridization using an HNF-4 probe corresponding to the deleted exons. 


\section{Acknowledgments}

We thank A. Bern and M. Jasin for the 129 mouse genomic library. We are also grateful to B. Herrman and C. Wright for providing Brachyury and Mox-1 plasmids. We thank Sundeep Kalantry for essential technical assistance. D.C.W. is a Howard Hughes Medical Institute Predoctoral Fellow. V.R.P. was partially funded by National Research Service Award Training grant GM 07982-09. This research was supported by National Institutes of Health grants HD06910 to R.F.B. and CA16006 to J.E.D.

The publication costs of this article were defrayed in part by payment of page charges. This article must therefore be hereby marked "advertisement" in accordance with 18 USC section 1734 solely to indicate this fact.

\section{References}

Ang, S.-L., A. Wierda, D. Wong, K.A. Stevens, S. Cascio, J. Rossant, and K.S. Zaret. 1993. The formation and maintenance of the definitive endodermal lineage in the mouse: Involvement of $\mathrm{HNF} 3 /$ forkhead proteins. Development 119: 1301-1315.

Beckman, D.A., T.R. Koszalka, M. Jensen, and R.L. Brent. 1990. Experimental manipulation of the rodent visceral yolk sac. Teratology 41: 395-404.

Beddington, R.S.P., P. Rashbass, and V. Wilson. 1992. Brachyury-A gene affecting mouse gastrulation and early organogenesis. Development (Suppl.) 157-165.

Bennett, D. 1975. The T-locus of the mouse. Cell 6: 441-4454.

Bennett, D. and L.C. Dunn. 1958. Effects on embryonic development of a group of genetically similar lethal alleles derived from different populations of wild house mice. J. Morphol. 103: 135-157.

Candia, A.F., J. Hu, J. Crosby, P.A. Lalley, D. Noden, J.H. Nadeau, and C.V. Wright. 1992. Mox-1 and Mox-2 define a novel homeobox gene family and are differentially expressed during early mesodermal patterning in mouse embryos. Development 116: 1123-1136.

Clark, K.L., E.D. Halay, E. Lai, and S.K. Burley. 1993. Co-crystal structure of the HNF-3/fork head DNA-recognition motif resembles histone H5. Nature 364: 412-420.

DeGregori, J., A. Russ, H. von Melchner, H. Rayburn, P. Priyaranjan, N.A. Jenkins, N.G. Copeland, and H.E Ruley. 1994. A murine homolog of the yeast RNAl gene is required for postimplantation development. Genes \& Dev. 8: 265276.

Duncan, S.A., K. Manova, W.S. Chen, P. Hoodless, D. Weinstein, R.F. Bachvarova, and J.E. Darnell Jr. 1994. Expression of transcription factor HNF-4 in the extraembryonic endoderm, gut, and nephrogenic tisse of the developing mouse embryo: HNF-4 is a marker for primary endoderm in the implanting blastocyst. Proc. Natl. Acad. Sci. 91: 7598-7602.

Ebersole, T., F. Lai, and K. Artzt. 1992. New molecular markers for the distal end of the $t$-complex and their relationship to mutations affecting development. Genetics 131: 175-182.

Gavrieli, Y., Y. Sherman, and S.A. Ben-Sasson. 1992. Identification of programmed cell death in situ via specific labeling of nuclear DNA fragmentation. J. Cell Biol. 119: 493-501.

Green, M.C. 1989. Catalog of mutant genes and polymorphic loci. In Genetic variants and strains of the laboratory mouse (ed. M.F. Lyon and A.G. Searle), pp. 12-403. Oxford University Press, New York.

Herrmann, B.G. 1991. Expression pattern of the Brachyury gene in whole-mount $T^{\text {Wis }} / T^{\text {Wis }}$ mutant embryos. Development 113: 913-917.
Herrmann, B.G., S. Labeit, A. Poustka, T.R. King, and H. Lehrach. 1990. Cloning of the $T$ gene required in mesoderm formation in the mouse. Nature 343: 617-622.

Holdener-Kenny, B., S.K. Sharan, and T. Magnuson. 1992. Mouse albino-deletions: From genetics to genes to development. BioEssays 14: 831-839.

Hooper, M., K. Hardy, A. Handyside, S. Hunter, and M. Monk. 1987. HPRT-deficient (Lesch-Nyhan) mouse embryos derived from germline colonization by cultured cells. Nature 326: 292-295.

Iannaccone, P.M., X. Zhou, M. Khokha, D. Boucher, and M.R. Kuehn. 1992. Insertional mutation of a gene involved in growth regulation of the early mouse embryo. Dev. Dyn. 194: 198-208.

Jollie, W.P. 1990. Development, morphology, and function of the yolk sac placenta of laboratory rodents. Teratology 41: 361-381.

Kadokawa, Y., Y. Kato, and G. Eguchi. 1987. Cell lineage analysis of the primary and visceral endoderm of mouse embryos cultured in vitro. Cell Differ. 21: 69-76.

Kispert, A. and B.G. Herrmann. 1994. Immunohistochemical analysis of the Brachyury protein in wild-type and mutant mouse embryos. Dev. Biol. 161: 179-193.

Kuo, C.J., P.B. Conley, L. Chen, F.M. Sladek, J.E. Darnell Jr., and G.R. Crabtree. 1992. A transcriptional hierarchy involved in mammalian cell-type specification. Nature 355: 458-460.

Lai, E., V.R. Prezioso, W. Tao, W.S. Chen, and J.E. Darnell Jr. 1991. Hepatocyte nuclear factor $3 \alpha$ belongs to gene family that is homologous to the Drosophila homeotic gene fork head. Genes \& Dev. 5: 416-427.

Lai, E., K.L. Clark, S.K. Burley, and J.E. Darnell Jr. 1993. Hepatocyte nuclear factor $3 /$ fork head or "winged helix" proteins: A family of transcription factors of diverse biologic function. Proc, Natl. Acad. Sci. 90: 10421-10423.

Lee, J.J., G. Radice, C.P. Perkins, and F. Costantini. 1992. Identification and characterization of a novel, evolutionarily conserved gene disnupted by the murine $H \beta 58$ embryonic lethal transgene insertion. Development 115: 277-288.

Li, E., T.H. Bestor, and R. Jaenisch. 1992. Targeted mutation of the DNA methyltransferase gene results in embryonic lethality. Cell 69: 915-926.

Marchuk, D., M. Drumm, A. Saulino, and F.S. Collins. 1991. Construction of $\mathrm{T}$-vectors, a rapid and general system for direct cloning of unmodified PCR products. Nucleic Acids Res. 19: 1154.

Monaghan, A.P., K.H. Kaestner, E. Grau, and G. Schutz. 1993. Postimplantation expression patterns indicate a role for the mouse forkhead/HNF- $3 \alpha, \beta$, and $\gamma$ genes in determination of the definitive endoderm, chordamesoderm and neurectoderm. Development 119: 567-578.

Parr, M.B. and E.L. Parr. 1986. Permeability of the primary decidual zone in the rat uterus: Studies using fluorescein-labeled proteins and dextrans. Biol. Reprod. 34: 393-403.

Plump, A.S., J.D. Smith, T. Hayek, K. Aalto-Setaa, A. Walsh, J.G. Verstuyft, E.M. Rubin, and J.L. Breslow. 1992. Severe hypercholesterolemia and atherosclerosis in apolipoprotein E-deficient mice created by homologous recombination in ES cells. Cell 71: 343-353.

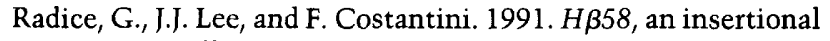
mutation affecting early postimplantation development of the mouse embryo. Development 111: 801-811.

Raff, M.C. 1992. Social controls on cell survival and cell death. Nature 356: 397-400.

Robertson, E.J. 1987. Embryo-derived stem cell lines. In Teratocarcinomas and embryonic stem cells: A practical approach (ed. E.J. Robertson), pp. 71-112. IRL Press, Oxford, UK. 
Robertson, E.J., F.L. Conlon, K.S. Barth, F. Costantini, and J.J. Lee. 1991. Use of embryonic stem cells to study mutations affecting postimplantation development in the mouse. Postimplantation development in the mouse, CIBA Found. Symp. 165: 237-250.

Ruiz i Altaba, A., V.R. Prezioso, J.E. Darnell, and T.M. Jessell. 1993. Sequential expression of HNF-3 $\alpha$ and HNF-3 $\beta$ by embryonic organizing centers: The dorsal lip/node, notochord and floor plate. Mech. Dev. 44: 91-108.

Sasaki, H. and B.L.M. Hogan. 1993. Differential expression of multiple fork head related genes during gastrulation and axial pattern formation in the mouse embryo. Development 118: 47-59.

Silver, L.M. 1985. Mouse $t$ haplotypes. Annu. Rev. Genet. 19: 179-208.

Sladek, F.M. 1994. Hepatocyte Nuclear Factor 4 (HNF-4). In Transcriptional regulation of liver specific genes (ed. F. Tronch and M. Yanish), R.G. Landes Company, Austin, TX. (In press).

Sladek, F.M., W. Zhong, E. Lai, and J.E. Darnell Jr. 1990. Liverenriched transcription factor HNF-4 is a novel member of the steroid hormone receptor superfamily. Genes $\Leftrightarrow \mathrm{Dev}$. 4: 2353-2365.

Thomas, T., B.R. Southwell, G. Schreiber, and A. Jaworowski. 1990. Plasma protein synthesis and secretion in the visceral yolk sac of the fetal rat: Gene expression, protein synthesis and secretion. Placenta 11: 413-430.

Tybulewicz, V.L.J., C.E. Crawford, P.K. Jackson, R.T. Bronson, and R.C. Mulligan. 1991. Neonatal lethality and lymphopenia in mice with a homozygous disruption of the c-abl protooncogene. Cell 65: 1153-1163.

Weige, D., G. Jürgens, F. Küttner, E. Seifert, and H. Jäckle. 1989. The homeotic gene fork head encodes a nuclear protein and is expressed in the terminal regions of the Drosophila embryo. Cell 59: 645-658.

Weinstein, D.C., A. Ruiz i Altaba, W.S. Chen, P. Hoodless, V.R. Prezioso, T.M. Jessell, and J.E. Darnell Jr. 1994. The wingedhelix transcription factor $H N F-3 \beta$ is required for notochord development in the mouse embryo. Cell 78: 575-588.

Wilkinson, D.G., S. Bhatt, and B.G. Herrmann. 1990. Expression pattern of the mouse $T$ gene and its role in mesoderm formation. Nature 343: 657-659.

Xanthopoulos, K.G., V.R. Prezioso, W.S. Chen, S.M. Sladek, R. Cortese, and J.E. Darnell Jr. 1991. The different tissue transcription patterns of genes for HNF-1, C/EBP, HNF-3 and HNF-4 protein factors that govern liver-specific transcription. Proc. Natl. Acad. Sci. 88: 3807-3811.

Zhong, W., F.M. Sladek, and J.E. Darnell Jr. 1993. The expression pattern of a Drosophila homolog to the mouse transcription factor HNF-4 suggests a determinative role in gut formation. EMBO I. 12: 537-544.

Zhou, X., H. Sasaki, L. Lowe, B.L.M. Hogan, and M.R. Kuehn. 1993. Nodal is a novel TGF-like gene expressed in the mouse node during gastrulation. Nature 361: 543-547. 


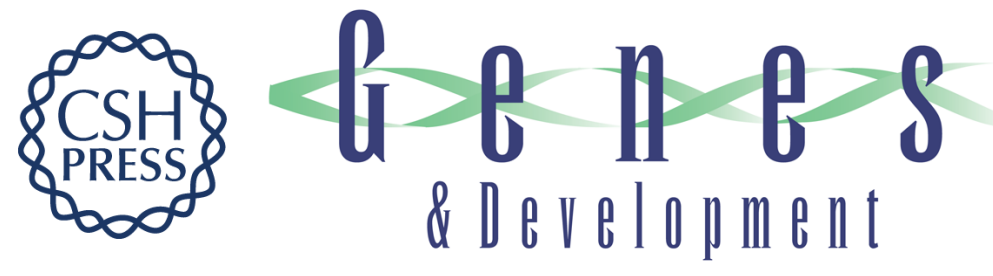

\section{Disruption of the HNF-4 gene, expressed in visceral endoderm, leads to cell death in embryonic ectoderm and impaired gastrulation of mouse embryos.}

W S Chen, K Manova, D C Weinstein, et al.

Genes Dev. 1994, 8:

Access the most recent version at doi:10.1101/gad.8.20.2466

References This article cites 42 articles, 14 of which can be accessed free at:

http://genesdev.cshlp.org/content/8/20/2466.full.html\#ref-list-1

License

Email Alerting Receive free email alerts when new articles cite this article - sign up in the box at the top Service right corner of the article or click here.

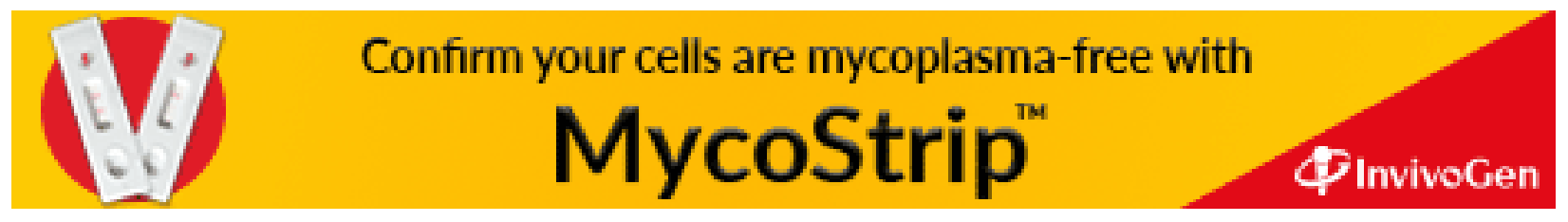

